\title{
Once- versus twice-weekly carfilzomib in relapsed and refractory multiple myeloma by select patient characteristics: phase 3 A.R.R.O.W. study subgroup analysis
}

\author{
Meletios A. Dimopoulos ${ }^{1}$, Ruben Niesvizky ${ }^{2}$, Katja Weise ${ }^{3,4}$, David S. Siegel ${ }^{5}$, Roman Hajek ${ }^{6}$, María-Victoria Mateos (107, \\ Michele Cavo ${ }^{8}$, Mei Huang ${ }^{9}$, Anita Zahlten-Kumeli ${ }^{9}$ and Philippe Moreau ${ }^{10}$
}

\begin{abstract}
The phase 3 A.R.R.O.W. study demonstrated that treatment with once-weekly carfilzomib $\left(70 \mathrm{mg} / \mathrm{m}^{2}\right)$ and dexamethasone (once-weekly $\mathrm{Kd} 70 \mathrm{mg} / \mathrm{m}^{2}$ ) improved progression-free survival compared with twice-weekly carfilzomib $\left(27 \mathrm{mg} / \mathrm{m}^{2}\right.$ ) and dexamethasone (twice-weekly $\mathrm{Kd} 27 \mathrm{mg} / \mathrm{m}^{2}$ ) in patients with relapsed and refractory multiple myeloma (RRMM; median, 11.2 versus 7.6 months; hazard ratio $[\mathrm{HR}]=0.69 ; 95 \%$ confidence interval, $0.54-0.88$; $P=0.0029$ ). Once-weekly dosing also improved response rates and depth of response. We performed a subgroup analysis from A.R.R.O.W. according to age $(<65,65-74$, or $\geq 75$ years), renal function (creatinine clearance $<50, \geq 50-<80$, or $\geq 80 \mathrm{~mL} / \mathrm{min}$ ), number of prior therapies (2 or 3), and bortezomib-refractory status (yes or no). Compared with twiceweekly $\mathrm{Kd} 27 \mathrm{mg} / \mathrm{m}^{2}$, once-weekly $\mathrm{Kd} 70 \mathrm{mg} / \mathrm{m}^{2}$ reduced the risk of progression or death $(H \mathrm{R}=0.60-0.85)$ and increased overall response rates in nearly all the examined subgroups, consistent with reports in the overall A.R.R.O.W. population. The safety profiles of once-weekly $\mathrm{Kd} 70 \mathrm{mg} / \mathrm{m}^{2}$ across subgroups were also generally consistent with those in the overall population. Findings from this subgroup analysis generally demonstrate a favorable benefit-risk profile of once-weekly $\mathrm{Kd} 70 \mathrm{mg} / \mathrm{m}^{2}$, further supporting once-weekly carfilzomib dosing as an appropriate treatment option for patients with RRMM, regardless of baseline patient and disease characteristics.
\end{abstract}

\section{Introduction}

Multiple myeloma (MM) is the third most common hematologic malignancy worldwide, characterized by excessive proliferation of monoclonal plasma cells ${ }^{1,2}$. The development of novel anti-MM agents has expanded treatment options for MM patients and improved outcomes $^{3}$. Despite recent treatment advances, MM remains incurable, with most patients relapsing and developing treatment-refractory disease ${ }^{1}$. Relapsed and refractory MM (RRMM) represents a challenging disease to treat,

\footnotetext{
Correspondence: Meletios A. Dimopoulos (mdimop@med.uoa.gr) ${ }^{1}$ National and Kapodistrian University of Athens, Athens, Greece

${ }^{2}$ Center for Myeloma, New York Presbyterian Hospital-Weill Cornell Medical Center, New York, NY, USA

Full list of author information is available at the end of the article.
}

given the heterogeneity of the disease and patient population $^{3-5}$.

Importantly, advanced age, Eastern Cooperative Oncology Group performance status (ECOG PS), International Staging System (ISS), renal impairment, exposure to multiple lines of therapy, refractoriness to treatment, and the presence of high-risk cytogenetics have been associated with poor prognosis and shorter survival in patients with $\mathrm{MM}$ (including $\mathrm{RRMM}{ }^{6-10}$. Therefore, there is a continued need to identify safe and efficacious and ultimately convenient treatments across the heterogeneous RRMM patient population. For treatments with demonstrated safety and efficacy, convenience represents an important factor for optimizing adherence and patient quality of life $\mathrm{e}^{11-13}$. 
Carfilzomib (K) is a second-generation proteasome inhibitor (PI) with selective, irreversible, robust, and welltolerated activity in $\mathrm{MM}$, both as single agent ${ }^{14}$ and in combination with dexamethasone $(\mathrm{Kd})$ or lenalidomide plus dexamethasone (KRd) when administered as a twiceweekly infusion in patients with RRMM ${ }^{15}$. Efficacy and safety of twice-weekly carfilzomib-based therapies were previously demonstrated in the phase 3 ASPIRE and ENDEAVOR trials ${ }^{16-19}$. Importantly, the treatment effect of carfilzomib was confirmed across several patient subgroups $^{20-26}$. The favorable benefit-risk profile of twiceweekly carfilzomib-based therapies versus standards of care (SOCs) provided an opportunity to consider the value of more convenient once-weekly carfilzomib therapy for patients with RRMM.

The randomized phase 3 A.R.R.O.W. trial (NCT02412878) was designed to evaluate a once-weekly carfilzomib dosing schedule compared with twice-weekly administration in patients with $\mathrm{RRMM}^{27}$. Patients were randomly assigned to receive once-weekly carfilzomib $\left(70 \mathrm{mg} / \mathrm{m}^{2}\right.$ ) with dexamethasone (once-weekly Kd70-mg/ $\mathrm{m}^{2}$ arm) or twice-weekly carfilzomib $\left(27 \mathrm{mg} / \mathrm{m}^{2}\right)$ with dexamethasone (twice-weekly $\mathrm{Kd} 27-\mathrm{mg} / \mathrm{m}^{2}$ arm). In the prespecified interim analysis, progression-free survival (PFS) and overall response rate (ORR) were improved in the once-weekly $\mathrm{Kd} 70-\mathrm{mg} / \mathrm{m}^{2}$ arm versus the twiceweekly $\mathrm{Kd} 27-\mathrm{mg} / \mathrm{m}^{2}$ arm (median PFS: 11.2 months versus 7.6 months; hazard ratio $[\mathrm{HR}]=0.69$; $95 \%$ confidence interval (CI), 0.54-0.88; $P=0.0029$; ORR: $62.9 \%$ versus $40.8 \%$ ). A greater proportion of once-weekly Kd70 $\mathrm{mg} / \mathrm{m}^{2}$ patients achieved a very good partial response or better $(\geq \mathrm{VGPR})$ and complete response or better $(\geq \mathrm{CR})$ compared with twice-weekly $\mathrm{Kd} 27 \mathrm{mg} / \mathrm{m}^{2}$ patients ( $\geq$ VGPR, $34.2 \%$ versus $13.4 \%$; $\geq \mathrm{CR}, 7.0 \%$ versus $1.7 \%$ ). Safety was generally comparable between the treatment $\mathrm{arms}^{27}$. Results from A.R.R.O.W. led to the recent approval of once-weekly $\mathrm{Kd} 70 \mathrm{mg} / \mathrm{m}^{2}$ for the treatment of patients with RRMM ${ }^{15,27}$. Furthermore, compared with twice-weekly $\mathrm{Kd} 27 \mathrm{mg} / \mathrm{m}^{2}$, once-weekly $\mathrm{Kd} 70 \mathrm{mg} / \mathrm{m}^{2}$ improved treatment adherence, patient satisfaction, and health-related quality of life in patients with $\mathrm{RRMM}^{13}$. Overall, these results support the value of once-weekly carfilzomib as an additional, more convenient treatment option for patients with RRMM. Here we report results from a pre-planned subgroup analysis of A.R.R.O.W. to evaluate treatment effects by age, renal function, number of prior therapies, bortezomib-refractory status, ISS, and ECOG PS.

\section{Methods}

\section{Study design and participants}

Full A.R.R.O.W. study design details have been published previously ${ }^{27}$. Eligibility criteria included: two or three previous lines of therapy, prior exposure to a PI and an immunomodulatory drug (IMiD), refractory to most recent therapy, measurable disease (per International Myeloma Working Group [IMWG] consensus criteria $^{28,29}$ ), ECOG PS of 0 or 1 , and calculated or measured creatinine clearance $(\mathrm{CrCL})$ of $\geq 30 \mathrm{~mL} / \mathrm{min}$. The primary endpoint of A.R.R.O.W. was PFS. Secondary endpoints included ORR, OS, and safety. The study protocol was approved by the institutional review boards or ethics committees of all participating sites, and all patients provided written informed consent.

\section{Procedures}

Patients were randomized (1:1) to receive once-weekly $\mathrm{Kd} 70 \mathrm{mg} / \mathrm{m}^{2}$ or twice-weekly $\mathrm{Kd} 27 \mathrm{mg} / \mathrm{m}^{2}$. Treatment was given in 28-day cycles until disease progression, unacceptable toxicity, or withdrawal of consent. Patients in the once-weekly $\mathrm{Kd} 70-\mathrm{mg} / \mathrm{m}^{2}$ group received carfilzomib on days 1,8 , and $15\left(20 \mathrm{mg} / \mathrm{m}^{2}\right.$ on day 1 [cycle 1 ]; $70 \mathrm{mg} / \mathrm{m}^{2}$ thereafter; 30 -min intravenous infusion). Twice-weekly $\mathrm{Kd} 27 \mathrm{mg} / \mathrm{m}^{2}$ patients received carfilzomib on days $1,2,8,9,15$, and $16\left(20 \mathrm{mg} / \mathrm{m}^{2}\right.$ on days 1 and 2 during cycle $1 ; 27 \mathrm{mg} / \mathrm{m}^{2}$ thereafter; 10 -min intravenous infusions). All patients received dexamethasone $(40 \mathrm{mg})$ on days $1,8,15$ (all cycles), and 22 (cycles 1-9 only).

\section{Subgroups}

Patients in the intention-to-treat (ITT) population were grouped according to age $(<65,65-74$, or $\geq 75$ years), renal function (baseline CrCL $<50, \geq 50$ to $<80$, or $\geq 80 \mathrm{~mL} / \mathrm{min}$ ), prior lines of therapy ( 2 or 3 ), bortezomib-refractory status (yes or no), ECOG PS ( 0 or 1$)$, and ISS stage (stages 1 and 2 or stage 3 ). Within 21 days prior to randomization, adequate bone marrow and organ function assessments were performed at a central laboratory. Renal function was calculated using the Cockcroft and Gault formula as follows: [ $(140-$ Age $) \times$ Mass $(\mathrm{kg}) /(72 \times$ Creatinine $(\mathrm{mg} / \mathrm{dL})]$; results were multiplied by 0.85 for female patients. Patients were considered refractory to bortezomib if (A) they were non-responsive to any regimen containing bortezomib (i.e., best overall response was stable or progressive disease) or (B) disease progression occurred within 60 days of bortezomib treatment discontinuation $^{27}$. Here we report analyses of PFS, ORR, and safety in these prespecified subgroups. OS was not included because this data was not mature at the time of the interim analysis.

\section{Assessments}

PFS, ORR, and best overall response were assessed in the ITT population. Response and disease progression were evaluated from the time of randomization in accordance with the IMWG Uniform Response Criteria $^{28,29}$. Safety was assessed in all patients who received at least one dose of carfilzomib or dexamethasone. 


\section{Statistical analyses}

Median PFS was estimated using the Kaplan-Meier method. HRs and corresponding 95\% CIs were estimated using an unstratified Cox proportional hazards model. Comparisons between treatment arms were evaluated using an unstratified log-rank test. The Clopper-Pearson method was used to estimate $95 \%$ CIs for ORR. Mantel-Haenszel unadjusted estimates were used to estimate the odds ratio (OR) and corresponding 95\% CI. Comparisons between treatment arms were evaluated using Fisher exact test. Reported $P$ values are one sided and unadjusted for multiple comparisons.

\section{Data sharing}

Qualified researchers may request data from Amgen clinical studies. Complete details are available at the following: http://www.amgen.com/datasharing.

\section{Results}

\section{Patient enrollment}

The cutoff date for the pre-planned interim analysis was June $15,2017^{27}$. Within the ITT population $(N=478)$, 240 patients received once-weekly $\mathrm{Kd} 70 \mathrm{mg} / \mathrm{m}^{2}$ and 238 received twice-weekly $\mathrm{Kd} 27 \mathrm{mg} / \mathrm{m}^{2}$. Baseline characteristics were generally balanced between treatment arms across subgroups. Select characteristics with $\geq 10 \%$ difference between treatment arms are shown in Supplementary Tables $1-4$.

\section{Efficacy \\ Age}

In total, 208 patients $(43.5 \%)$ were aged $<65$ years (onceweekly $\mathrm{Kd} 70 \mathrm{mg} / \mathrm{m}^{2}, n=104$; twice-weekly $\mathrm{Kd} 27 \mathrm{mg} / \mathrm{m}^{2}$, $n=104), 192$ patients $(40.2 \%)$ were aged $65-74$ years $(n$ $=90 ; n=102)$, and $78(16.3 \%)$ patients were aged $\geq 75$ years $(n=46 ; n=32)$. The median PFS in patients aged $<65$ years was longer in the once-weekly $\mathrm{Kd} 70-\mathrm{mg} / \mathrm{m}^{2}$ arm compared with the twice-weekly $\mathrm{Kd} 27-\mathrm{mg} / \mathrm{m}^{2}$ group (12.2 versus 5.6 months; $\mathrm{HR}=0.60 ; 95 \% \mathrm{CI}, 0.42-0.86 ; P$ $=0.0024$; Fig. 1). Among patients aged $65-74$ and $\geq 75$ years, median PFS (once-weekly $\mathrm{Kd} 70 \mathrm{mg} / \mathrm{m}^{2}$ versus twice-weekly $\mathrm{Kd} 27 \mathrm{mg} / \mathrm{m}^{2}$ ) was 9.2 versus 8.4 months $(\mathrm{HR}=0.84 ; 95 \% \mathrm{CI}, 0.58-1.23 ; P=0.1866)$ and 12.2 versus 9.5 months $(\mathrm{HR}=0.80 ; 95 \% \mathrm{CI}, 0.43-1.48 ; P=$ $0.2385)$, respectively.

Response by age is shown in Table 1 . ORR was improved with once-weekly $\mathrm{Kd} 70 \mathrm{mg} / \mathrm{m}^{2}$ versus twiceweekly $\mathrm{Kd} 27 \mathrm{mg} / \mathrm{m}^{2}$ for all age subgroups. ORRs (onceweekly $\mathrm{Kd} 70 \mathrm{mg} / \mathrm{m}^{2}$ versus twice-weekly $\mathrm{Kd} 27 \mathrm{mg} / \mathrm{m}^{2}$ ) were $64.4 \%$ versus $34.6 \%$ (OR, 3.42; 95\% CI, 1.94-6.05) in patients aged $<65$ years, $60.0 \%$ versus $42.2 \%$ (OR, 2.06; 95\% CI, 1.16-3.66) in patients aged 65-74 years, and $65.2 \%$ versus $56.3 \%$ (OR, $1.46 ; 95 \% \mathrm{CI}, 0.58-3.68$ ) in patients aged $\geq 75$ years. Regardless of age, a higher proportion of patients treated with once-weekly Kd70 mg/ $\mathrm{m}^{2}$ achieved $\mathrm{a} \geq \mathrm{VGPR}$ and $\mathrm{a} \geq \mathrm{CR}$ versus twice-weekly $\mathrm{Kd} 27 \mathrm{mg} / \mathrm{m}^{2}$ (Table 1 ).

\section{Renal function}

Eighty-five (17.8\%) patients had baseline CrCL $<50 \mathrm{~mL} / \mathrm{min}$ (once-weekly $\mathrm{Kd} 70 \mathrm{mg} / \mathrm{m}^{2}, n=50$; twiceweekly $\left.\mathrm{Kd} 27 \mathrm{mg} / \mathrm{m}^{2}, n=35\right), 202$ (42.3\%) patients had baseline $\mathrm{CrCL} \geq 50$ to $<80 \mathrm{~mL} / \mathrm{min}(n=91 ; n=111)$, and 190 (39.7\%) patients had baseline $\mathrm{CrCL} \geq 80 \mathrm{~mL} / \mathrm{min}$ ( $n=$ 99; $n=91$ ). Median PFS (once-weekly $\mathrm{Kd} 70 \mathrm{mg} / \mathrm{m}^{2}$ versus twice-weekly $\mathrm{Kd} 27 \mathrm{mg} / \mathrm{m}^{2}$ ) was 10.3 versus 8.7 months $(\mathrm{HR}=0.85 ; 95 \% \mathrm{CI}, 0.48-1.53 ; P=0.2931)$ in patients with $\mathrm{CrCL}<50 \mathrm{~mL} / \mathrm{min}, \quad 12.4$ versus 7.6 months $(\mathrm{HR}=0.64 ; 95 \% \mathrm{CI}, 0.44-0.94 ; P=0.0112)$ in patients with $\mathrm{CrCL} \geq 50$ to $<80 \mathrm{~mL} / \mathrm{min}$, and 8.6 versus 7.5 months (HR $=0.71 ; 95 \% \mathrm{CI}, 0.49-1.02 ; P=0.0305)$ in patients with $\mathrm{CrCL} \geq 80 \mathrm{~mL} / \mathrm{min}$ (Fig. 1).

ORR was improved with once-weekly $\mathrm{Kd} 70 \mathrm{mg} / \mathrm{m}^{2}$ across all renal function subgroups (Table 1). The ORRs for once-weekly $\mathrm{Kd} 70 \mathrm{mg} / \mathrm{m}^{2}$ versus twice-weekly $\mathrm{Kd} 27$ $\mathrm{mg} / \mathrm{m}^{2}$ were $50.0 \%$ versus $40.0 \%$ (OR, $1.50 ; 95 \% \mathrm{CI}$, $0.63-3.60)$ in patients with $\mathrm{CrCL}<50 \mathrm{~mL} / \mathrm{min}, 65.9 \%$ versus $39.6 \%$ (OR, 2.95; 95\% CI, 1.66-5.25) in patients with $\mathrm{CrCL} \geq 50$ to $<80 \mathrm{~mL} / \mathrm{min}$, and $66.7 \%$ versus $42.9 \%$ (OR, 2.67; 95\% CI, 1.48-4.81) in patients with $\mathrm{CrCL}$ $\geq 80 \mathrm{~mL} / \mathrm{min}$. A greater proportion of once-weekly Kd70$\mathrm{mg} / \mathrm{m}^{2}$ patients achieved $\geq \mathrm{VGPR}$ and $\geq \mathrm{CR}$ versus twiceweekly $\mathrm{Kd} 27 \mathrm{mg} / \mathrm{m}^{2}$ across all renal function subgroups (Table 1).

\section{Prior lines of therapy}

Within the ITT population, 241 (50.4\%) patients received two prior therapies (once-weekly $\mathrm{Kd} 70 \mathrm{mg} / \mathrm{m}^{2}, n$ =116; twice-weekly $\left.\mathrm{Kd} 27 \mathrm{mg} / \mathrm{m}^{2}, n=125\right)$ and 237 (49.6\%) patients received three prior therapies $(n=124 ; n$ $=113$ ). Median PFS was comparable or better in patients treated with once-weekly $\mathrm{Kd} 70 \mathrm{mg} / \mathrm{m}^{2}$ vs twice-weekly $\mathrm{Kd} 27 \mathrm{mg} / \mathrm{m}^{2}$ according to prior number of therapies. Median PFS (once-weekly $\mathrm{Kd} 70 \mathrm{mg} / \mathrm{m}^{2}$ versus twiceweekly $\mathrm{Kd} 27 \mathrm{mg} / \mathrm{m}^{2}$ ) was 12.1 versus 7.6 months $(\mathrm{HR}=$ 0.61 ; 95\% CI, $0.43-0.86 ; P=0.0023$ ) in the two prior therapies subgroup and 8.9 versus 7.9 months $(\mathrm{HR}=0.82$; 95\% CI, $0.59-1.15 ; P=0.1244$ ) in the three prior therapy subgroup (Fig. 2).

ORRs for once-weekly $\mathrm{Kd} 70 \mathrm{mg} / \mathrm{m}^{2}$ versus twice-weekly $\mathrm{Kd} 27 \mathrm{mg} / \mathrm{m}^{2}$ were $62.9 \%$ versus $40.8 \%$ (OR, 2.46; $95 \% \mathrm{CI}$, $1.47-4.14)$ in the two prior line subgroup and $62.9 \%$ versus $40.7 \%$ (OR, 2.47; 95\% CI, 1.46-4.17) in the three prior line subgroup, respectively. Patients treated with once-weekly $\mathrm{Kd} 70 \mathrm{mg} / \mathrm{m}^{2}$ achieved higher rates of $\geq$ VGPR and $\geq$ CR versus those treated with twice-weekly $\mathrm{Kd} 27 \mathrm{mg} / \mathrm{m}^{2}$ regardless of the number of prior lines of therapy (Table 2). 
A

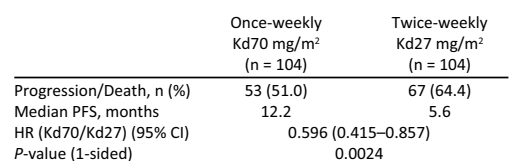
HR (Kd70/Kd27) (95\% $P$-value (1-sided)

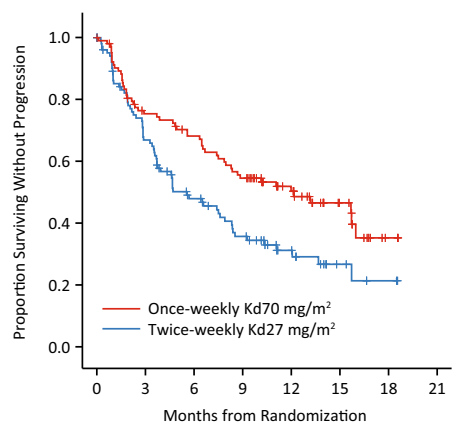

Number of Subjects at Risk:

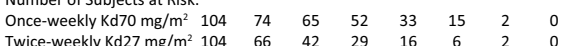

C
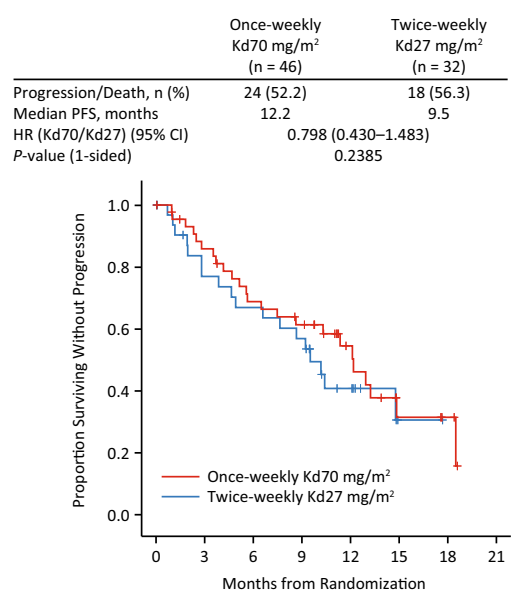

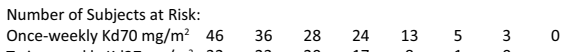
$\begin{array}{llllllll}\text { Once-weekly Kd70 mg/m } & 46 & 36 & 28 & 24 & 13 & 5 & 3 \\ \text { Twice-weekly Kd27 mg/m } & 32 & 23 & 20 & 17 & 8 & 1 & 0\end{array}$

E
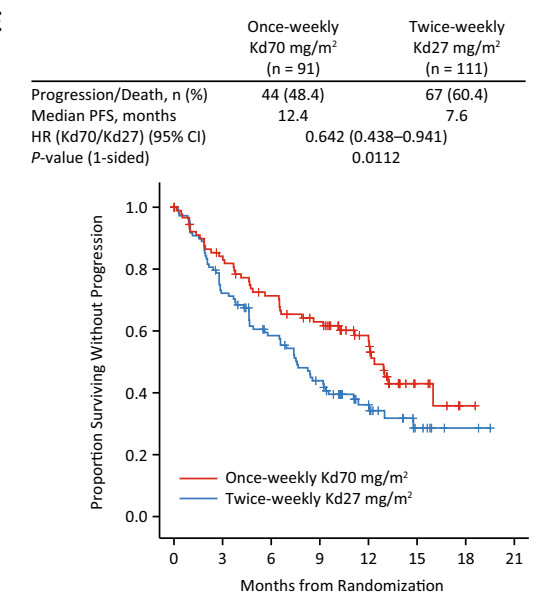

Number of Subjects at Risk:

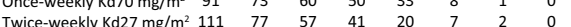

D
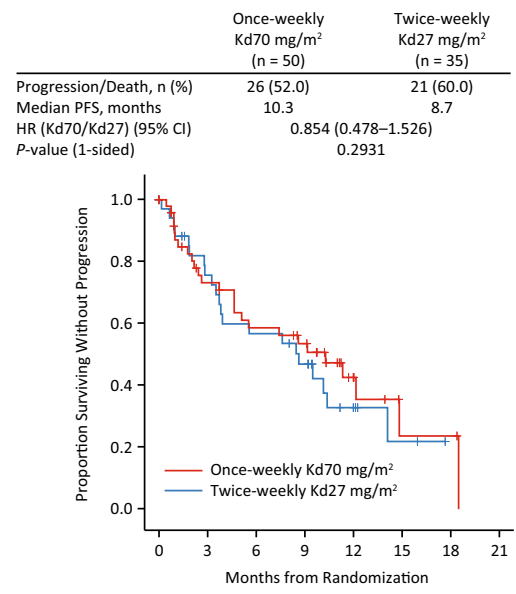

$\begin{array}{lllllllll}\text { Number of Subjects at Risk: } & & & & & & \\ \text { Once-weekly } \mathrm{Kd} 70 \mathrm{mg} / \mathrm{m}^{2} & 50 & 31 & 24 & 20 & 8 & 2 & 2 & 0\end{array}$ $\begin{array}{lllllllll}\text { Twice-weekly } \mathrm{Kd} 27 \mathrm{mg} / \mathrm{m}^{2} & 35 & 24 & 18 & 14 & 6 & 2 & 0\end{array}$

$\mathbf{F}$
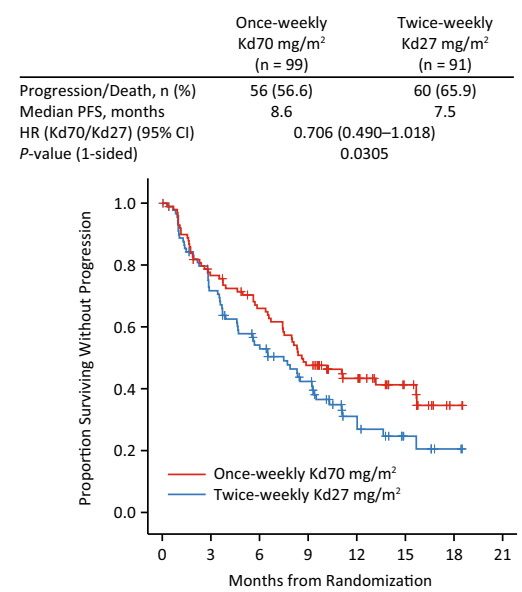

Number of Subjects at Risk:

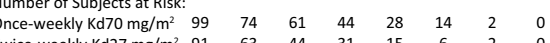

Fig. 1 Kaplan-Meier curves for progression-free survival by subgroups' age and renal function. $\mathbf{a}<65$ years, $\mathbf{b} 65-74$ years, $\mathbf{c} \geq 75$ years, d creatinine clearance $(\mathrm{CrCL})<50 \mathrm{~mL} / \mathrm{min}$, e $\mathrm{CrCL} \geq 50-<80 \mathrm{~mL} / \mathrm{min}, \mathbf{f} \mathrm{CrCL} \geq 80 \mathrm{~mL} / \mathrm{min}$. 


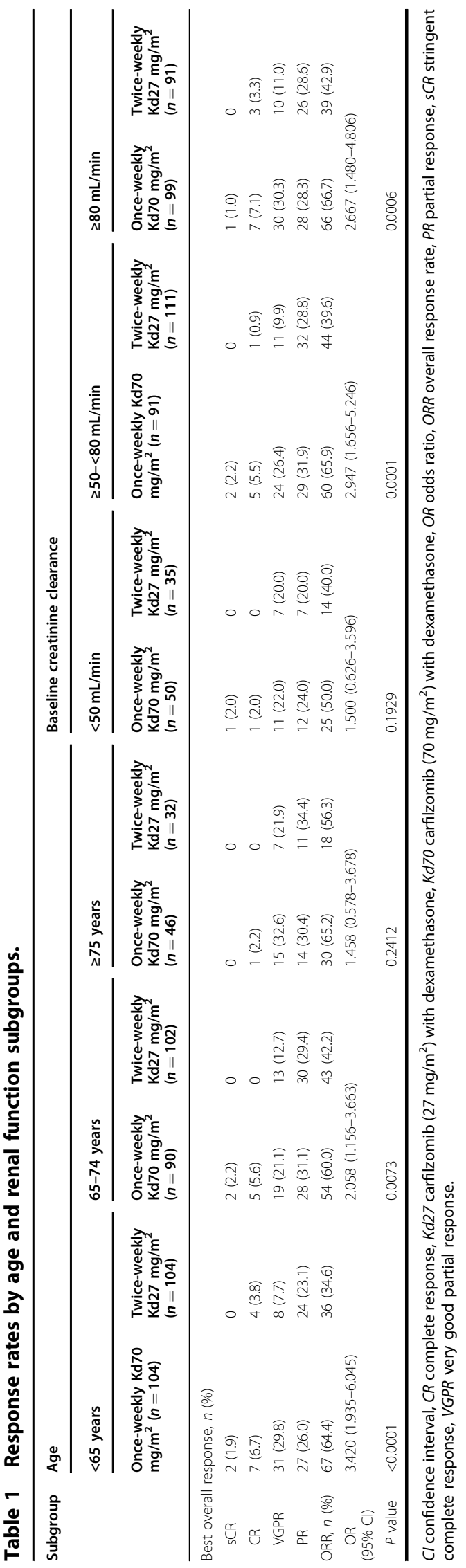

\section{Bortezomib-refractory status}

Within the ITT population, 201 (42.1\%) patients were bortezomib refractory (once-weekly $\mathrm{Kd} 70 \mathrm{mg} / \mathrm{m}^{2}, n=$ 111; twice-weekly $\left.\mathrm{Kd} 27 \mathrm{mg} / \mathrm{m}^{2}, n=90\right)$ and 277 (57.9\%) patients were not bortezomib refractory $(n=129 ; n=$ 148). Median PFS (once-weekly $\mathrm{Kd} 70 \mathrm{mg} / \mathrm{m}^{2}$ versus twice-weekly $\mathrm{Kd} 27 \mathrm{mg} / \mathrm{m}^{2}$ ) was 10.3 versus 7.4 months $(\mathrm{HR}=0.73 ; 95 \% \mathrm{CI}, 0.51-1.05 ; P=0.0440)$ in patients with disease refractory to bortezomib and 12.1 versus 7.7 months $(\mathrm{HR}=0.70 ; 95 \% \mathrm{CI}, 0.51-0.96 ; P=0.0124)$ in patients with disease not refractory to bortezomib (Fig. 2). Twice-weekly $\mathrm{Kd} 27 \mathrm{mg} / \mathrm{m}^{2}$ had similar median PFS outcomes, irrespective of disease sensitivity to bortezomib.

Patients treated with once-weekly $\mathrm{Kd} 70 \mathrm{mg} / \mathrm{m}^{2}$ demonstrated higher response rates compared with those treated with twice-weekly $\mathrm{Kd} 27 \mathrm{mg} / \mathrm{m}^{2}$ across subgroups based on disease sensitivity to bortezomib. ORRs (onceweekly $\mathrm{Kd} 70 \mathrm{mg} / \mathrm{m}^{2}$ versus twice-weekly $\mathrm{Kd} 27 \mathrm{mg} / \mathrm{m}^{2}$ ) were $57.7 \%$ versus $42.2 \%$ (OR, 1.86 ; $95 \% \mathrm{CI}, 1.06-3.27)$ in patients with bortezomib-refractory disease and $67.4 \%$ versus $39.9 \%$ (OR, 3.13; 95\% CI, 1.91-5.12) in patients with disease not refractory to bortezomib. Regardless of bortezomib-refractory status, a greater proportion of once-weekly Kd70-mg $/ \mathrm{m}^{2}$ patients achieved $\geq$ VGPR and $\geq \mathrm{CR}$ versus twice-weekly Kd27-mg/m $\mathrm{m}^{2}$ patients (Table 2 ).

\section{Safety \\ Age}

The median number of cycles patients received carfilzomib (once-weekly Kd70 mg/m ${ }^{2}$ and twice-weekly Kd27 $\mathrm{mg} / \mathrm{m}^{2}$ ) was 11 and 6 cycles in patients aged $<65$ years, 9 and 9 cycles in patients aged $65-74$ years, and 10 and 10 cycles in patients aged $\geq 75$ years, respectively. Median carfilzomib treatment duration was higher in the onceweekly $\mathrm{Kd} 70-\mathrm{mg} / \mathrm{m}^{2}$ treatment arm relative to the twiceweekly $\mathrm{Kd} 27-\mathrm{mg} / \mathrm{m}^{2}$ treatment arm in patients aged $<65$ years (41.1 and 21.3 weeks, respectively); median treatment duration was 33.1 and 34.9 weeks in patients aged 65-74 years, and 40.1 and 37.3 weeks in patients aged $\geq 75$ years, respectively. Treatment-emergent adverse events (TEAEs) by age are shown in Table 3. The incidence of grade $\geq 3$ TEAEs (once-weekly $\mathrm{Kd} 70 \mathrm{mg} / \mathrm{m}^{2}$ and twiceweekly $\mathrm{Kd} 27 \mathrm{mg} / \mathrm{m}^{2}$ ) was $59.2 \%$ and $56.3 \%$ ( $<65$ years), $68.9 \%$ and $63.4 \%$ ( $65-74$ years), and $84.4 \%$ and $74.2 \%(\geq 75$ years), respectively. Rates of grade $\geq 3$ cardiac failure (once-weekly $\mathrm{Kd} 70 \mathrm{mg} / \mathrm{m}^{2}$ and twice-weekly $\mathrm{Kd} 27$ $\mathrm{mg} / \mathrm{m}^{2}$ ) were $1.0 \%$ and $5.8 \%, 5.6 \%$ and $2.0 \%$, and $2.2 \%$ and $6.5 \%$ in these age subgroups, respectively.

TEAEs leading to carfilzomib discontinuation (onceweekly $\mathrm{Kd} 70 \mathrm{mg} / \mathrm{m}^{2}$ and twice-weekly $\mathrm{Kd} 27 \mathrm{mg} / \mathrm{m}^{2}$ ) occurred at rates of $6.8 \%$ and $13.6 \%$ ( $<65$ years), $16.7 \%$ and $7.9 \%$ (65-74 years), and $17.8 \%$ and $16.1 \%$ ( $\geq 75$ years); rates of TEAEs leading to dexamethasone discontinuation were $8.7 \%$ and $13.6 \%, 18.9 \%$ and $7.9 \%$, and $20.0 \%$ and 


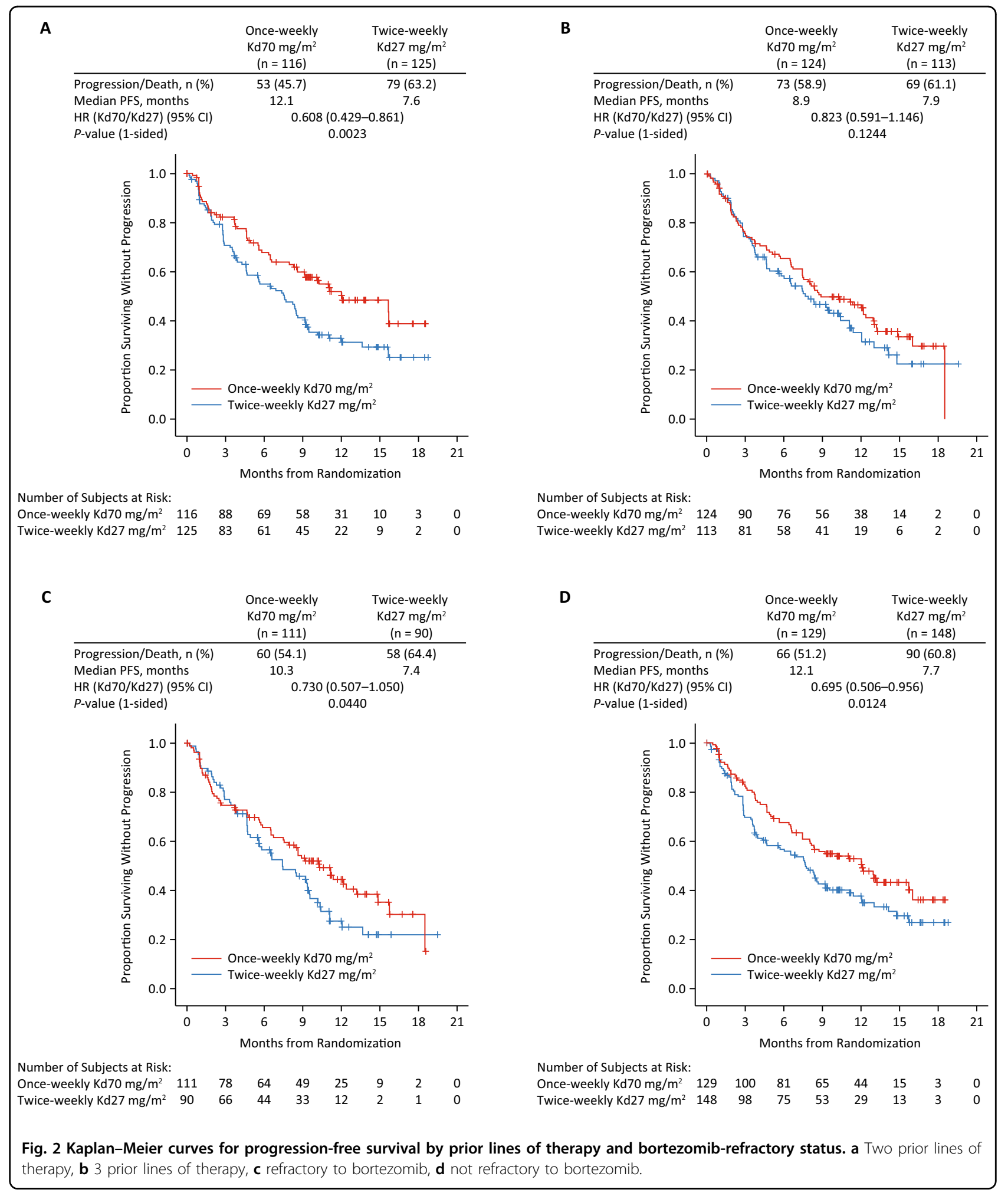

$16.1 \%$, respectively. Incidence of fatal TEAEs (onceweekly $\mathrm{Kd} 70 \mathrm{mg} / \mathrm{m}^{2}$ and twice-weekly $\mathrm{Kd} 27 \mathrm{mg} / \mathrm{m}^{2}$ ) was 9.7\% and $8.7 \%$ ( $<65$ years), $11.1 \%$ and $5.0 \%$ (65-74 years), and $4.4 \%$ and $12.9 \%$ ( $\geq 75$ years).

\section{Renal function}

TEAEs by renal function are shown in Table 3 . Rates of grade $\geq 3$ TEAEs by baseline CrCL (once-weekly Kd70 $\mathrm{mg} / \mathrm{m}^{2}$ and twice-weekly $\mathrm{Kd} 27 \mathrm{mg} / \mathrm{m}^{2}$ ) were $77.6 \%$ and 
Table 2 Response rates by prior lines of therapy and bortezomib-refractory status subgroups.

\begin{tabular}{|c|c|c|c|c|c|c|c|c|}
\hline \multirow[t]{3}{*}{ Subgroup } & \multicolumn{4}{|c|}{ Prior lines of therapy } & \multicolumn{4}{|c|}{ Bortezomib-refractory status } \\
\hline & \multicolumn{2}{|l|}{2 prior lines } & \multicolumn{2}{|l|}{3 prior lines } & \multicolumn{2}{|c|}{ Refractory to bortezomib } & \multicolumn{2}{|c|}{ Not refractory to bortezomib } \\
\hline & $\begin{array}{l}\text { Once-weekly } \\
\mathrm{Kd} 70 \mathrm{mg} / \mathrm{m}^{2} \\
(n=116)\end{array}$ & $\begin{array}{l}\text { Twice-weekly } \\
\mathrm{Kd} 27 \mathrm{mg} / \mathrm{m}^{2} \\
(n=125)\end{array}$ & $\begin{array}{l}\text { Once-weekly } \\
\mathrm{Kd} 70 \mathrm{mg} / \mathrm{m}^{2} \\
(n=124)\end{array}$ & $\begin{array}{l}\text { Twice-weekly } \\
\mathrm{Kd} 27 \mathrm{mg} / \mathrm{m}^{2} \\
(n=113)\end{array}$ & $\begin{array}{l}\text { Once-weekly } \\
\mathrm{Kd} 70 \mathrm{mg} / \mathrm{m}^{2} \\
(n=111)\end{array}$ & $\begin{array}{l}\text { Twice-weekly } \\
\mathrm{Kd} 27 \mathrm{mg} / \mathrm{m}^{2} \\
(n=90)\end{array}$ & $\begin{array}{l}\text { Once-weekly } \\
\mathrm{Kd} 70 \mathrm{mg} / \mathrm{m}^{2} \\
(n=129)\end{array}$ & $\begin{array}{l}\text { Twice-weekly } \\
\mathrm{Kd} 27 \mathrm{mg} / \mathrm{m}^{2} \\
(n=148)\end{array}$ \\
\hline \multicolumn{9}{|c|}{ Best overall response, $n$ (\%) } \\
\hline$s C R$ & $1(0.9)$ & 0 & $3(2.4)$ & 0 & 0 & 0 & $4(3.1)$ & 0 \\
\hline$C R$ & $10(8.6)$ & $4(3.2)$ & $3(2.4)$ & 0 & $7(6.3)$ & $2(2.2)$ & $6(4.7)$ & $2(1.4)$ \\
\hline VGPR & $32(27.6)$ & $14(11.2)$ & $33(26.6)$ & $14(12.4)$ & $23(20.7)$ & $4(4.4)$ & $42(32.6)$ & $24(16.2)$ \\
\hline$P R$ & $30(25.9)$ & $33(26.4)$ & $39(31.5)$ & $32(28.3)$ & $34(30.6)$ & $32(35.6)$ & $35(27.1)$ & $33(22.3)$ \\
\hline ORR, $n(\%)$ & $73(62.9)$ & $51(40.8)$ & $78(62.9)$ & $46(40.7)$ & $64(57.7)$ & $38(42.2)$ & $87(67.4)$ & $59(39.9)$ \\
\hline OR $(95 \% \mathrm{Cl})$ & \multicolumn{2}{|l|}{$2.463(1.466-4.139)$} & \multicolumn{2}{|c|}{$2.470(1.464-4.167)$} & \multicolumn{2}{|c|}{$1.863(1.061-3.271)$} & \multicolumn{2}{|c|}{$3.125(1.907-5.120)$} \\
\hline$P$ value & \multicolumn{2}{|l|}{0.0004} & \multicolumn{2}{|l|}{0.0004} & \multicolumn{2}{|l|}{0.0169} & \multicolumn{2}{|l|}{$<0.0001$} \\
\hline
\end{tabular}

$C I$ confidence interval, $C R$ complete response, $K d 27$ carfilzomib $\left(27 \mathrm{mg} / \mathrm{m}^{2}\right)$ with dexamethasone, $K d 70$ carfilzomib $\left(70 \mathrm{mg} / \mathrm{m}^{2}\right)$ with dexamethasone, $O R$ odds ratio, $O R R$ overall response rate, $P R$ partial response, $s C R$ stringent complete response, $V G P R$ very good partial response.

70.6\% $(\mathrm{CrCL}<50 \mathrm{~mL} / \mathrm{min}), 71.1 \%$ and $61.5 \%(\mathrm{CrCL} \geq 50$ to $<80 \mathrm{~mL} / \mathrm{min})$, and $59.6 \%$ and $59.3 \%(\mathrm{CrCL} \geq 80 \mathrm{~mL} /$ min). The incidence of grade $\geq 3$ cardiac failure (onceweekly $\mathrm{Kd} 70 \mathrm{mg} / \mathrm{m}^{2}$ and twice-weekly $\mathrm{Kd} 27 \mathrm{mg} / \mathrm{m}^{2}$ ) was $2.0 \%$ and $5.9 \%, 6.7 \%$ and $3.7 \%$, and $0 \%$ and $4.4 \%$ in these renal function subgroups, respectively.

TEAEs leading to carfilzomib discontinuation (onceweekly $\mathrm{Kd} 70 \mathrm{mg} / \mathrm{m}^{2}$ and twice-weekly $\mathrm{Kd} 27 \mathrm{mg} / \mathrm{m}^{2}$ ) occurred at rates of $28.6 \%$ and $14.7 \%(\mathrm{CrCL}<50 \mathrm{~mL} / \mathrm{min})$, $14.4 \%$ and $11.0 \%(\mathrm{CrCL} \geq 50$ to $<80 \mathrm{~mL} / \mathrm{min})$, and $3.0 \%$ and $11.0 \%(\mathrm{CrCL} \geq 80 \mathrm{~mL} / \mathrm{min})$; rates of TEAEs leading to dexamethasone discontinuation were $30.6 \%$ and $14.7 \%$, $16.7 \%$ and $11.0 \%$, and $5.1 \%$ and $11.0 \%$, respectively. Incidence of fatal TEAEs (once-weekly $\mathrm{Kd} 70 \mathrm{mg} / \mathrm{m}^{2}$ and twice-weekly $\left.\mathrm{Kd} 27 \mathrm{mg} / \mathrm{m}^{2}\right)$ was $18.4 \%$ and $17.6 \%(\mathrm{CrCL}<$ $50 \mathrm{~mL} / \mathrm{min}), 6.7 \%$ and $4.6 \%(\mathrm{CrCL} \geq 50$ to $<80 \mathrm{~mL} / \mathrm{min})$, and $7.1 \%$ and $7.7 \%(\mathrm{CrCL} \geq 80 \mathrm{~mL} / \mathrm{min})$.

\section{Prior lines of therapy}

TEAEs by prior lines of therapy are shown in Table 4 . The incidence of grade $\geq 3$ TEAEs (once-weekly Kd70 mg/ $\mathrm{m}^{2}$ and twice-weekly $\mathrm{Kd} 27 \mathrm{mg} / \mathrm{m}^{2}$ ) was $59.1 \%$ and $65.0 \%$ ( 2 prior lines) and $75.6 \%$ and $58.0 \%$ ( 3 prior lines). The incidence of grade $\geq 3$ cardiac failure (once-weekly Kd70 $\mathrm{mg} / \mathrm{m}^{2}$ and twice-weekly $\mathrm{Kd} 27 \mathrm{mg} / \mathrm{m}^{2}$ ) was $2.6 \%$ and $2.4 \%$ ( 2 prior lines) and $3.3 \%$ and $6.3 \%$ (3 prior lines).

TEAEs leading to carfilzomib discontinuation (onceweekly $\mathrm{Kd} 70 \mathrm{mg} / \mathrm{m}^{2}$ and twice-weekly $\mathrm{Kd} 27 \mathrm{mg} / \mathrm{m}^{2}$ ) occurred at rates of $13.0 \%$ and $9.8 \%$ (2 prior lines) and $12.2 \%$ and $13.4 \%$ ( 3 prior lines); rates of TEAEs leading to dexamethasone discontinuation were $16.5 \%$ and $9.8 \%$ (2 prior lines) and $13.0 \%$ and $13.4 \%$ (3 prior lines). The incidence of fatal TEAEs (once-weekly $\mathrm{Kd} 70 \mathrm{mg} / \mathrm{m}^{2}$ and twice-weekly $\mathrm{Kd} 27 \mathrm{mg} / \mathrm{m}^{2}$ ) was $8.7 \%$ and $6.5 \%$ (2 prior lines) and $9.8 \%$ and $8.9 \%$ (3 prior lines).

\section{Bortezomib-refractory status}

Rates of TEAEs by bortezomib-refractory status are shown in Table 4. Frequencies of grade $\geq 3$ TEAEs (onceweekly $\mathrm{Kd} 70 \mathrm{mg} / \mathrm{m}^{2}$ and twice-weekly $\mathrm{Kd} 27 \mathrm{mg} / \mathrm{m}^{2}$ ) were $68.2 \%$ and $61.8 \%$ (refractory to bortezomib) and $67.2 \%$ and $61.6 \%$ (not refractory to bortezomib). The frequencies of grade $\geq 3$ cardiac failure (once-weekly $\mathrm{Kd} 70 \mathrm{mg} / \mathrm{m}^{2}$ and twice-weekly $\mathrm{Kd} 27 \mathrm{mg} / \mathrm{m}^{2}$ ) by bortezomib-refractory status were $4.5 \%$ and $6.7 \%$ (refractory to bortezomib) and $1.6 \%$ and $2.7 \%$ (not refractory to bortezomib).

TEAEs leading to carfilzomib discontinuation (onceweekly $\mathrm{Kd} 70 \mathrm{mg} / \mathrm{m}^{2}$ and twice-weekly $\mathrm{Kd} 27 \mathrm{mg} / \mathrm{m}^{2}$ ) occurred at rates of $14.5 \%$ and $10.1 \%$ (refractory to bortezomib) and $10.9 \%$ and $12.3 \%$ (not refractory to bortezomib); frequencies of TEAEs leading to dexamethasone discontinuation were $14.5 \%$ and $10.1 \%$ (refractory to bortezomib) and $14.8 \%$ and $12.3 \%$ (not refractory to bortezomib). Rates of fatal TEAEs (once-weekly Kd70 $\mathrm{mg} / \mathrm{m}^{2}$ and twice-weekly $\mathrm{Kd} 27 \mathrm{mg} / \mathrm{m}^{2}$ ) were $6.4 \%$ and $7.9 \%$ (refractory to bortezomib) and $11.7 \%$ and $7.5 \%$ (not refractory to bortezomib).

\section{ECOG PS and ISS stage}

Rates of grade $\geq 3$ TEAEs of interest are shown in Supplementary Table 5 . The incidence of grade $\geq 3$ cardiac failure (once-weekly $\mathrm{Kd} 70 \mathrm{mg} / \mathrm{m}^{2}$ and twice-weekly Kd27 $\mathrm{mg} / \mathrm{m}^{2}$ ) by ECOG PS was $1.7 \%$ and $2.6 \%$ (ECOG PS of 0 ) and $4.2 \%$ and $5.9 \%$ (ECOG PS of 1 ). The rates of grade $\geq 3$ 


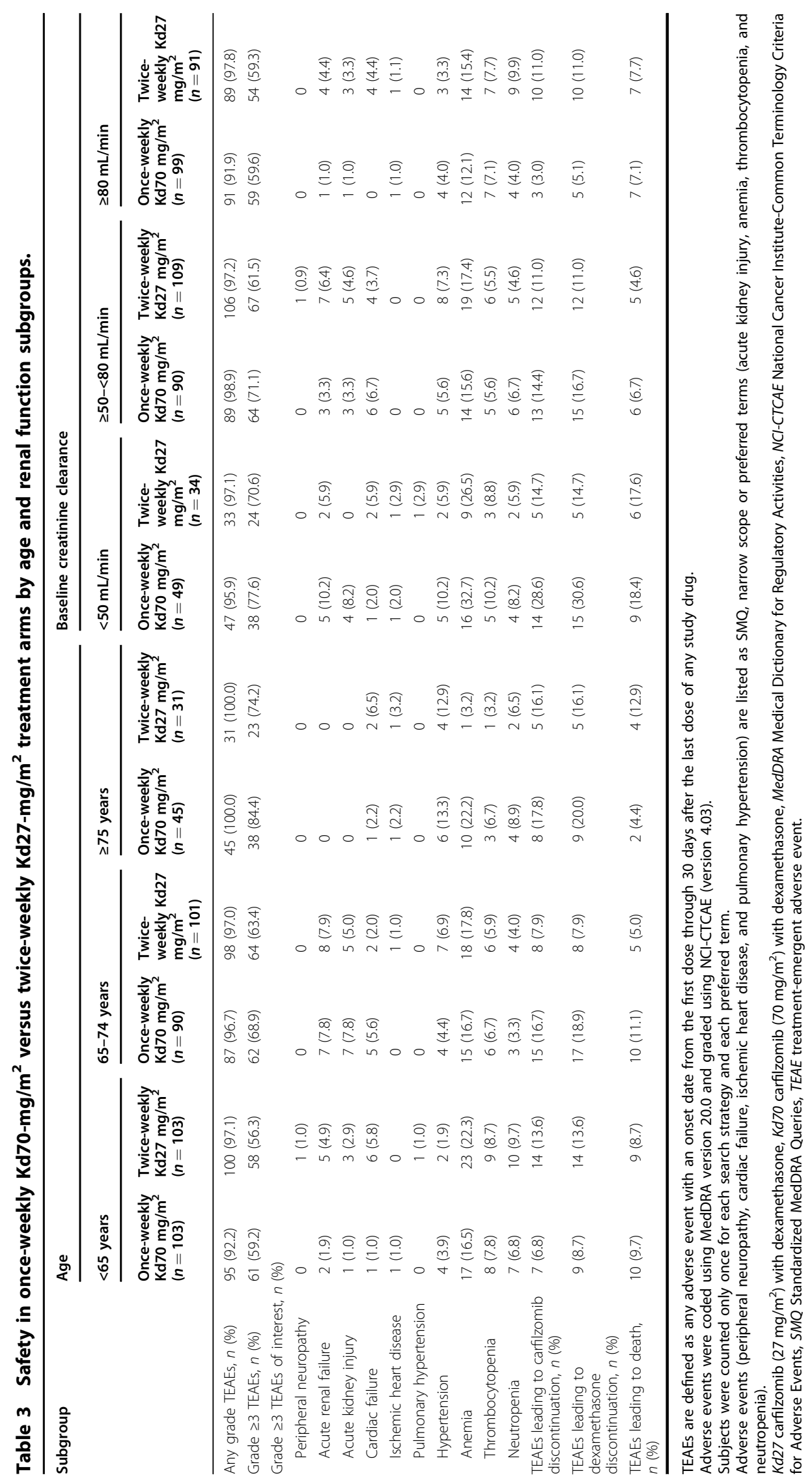




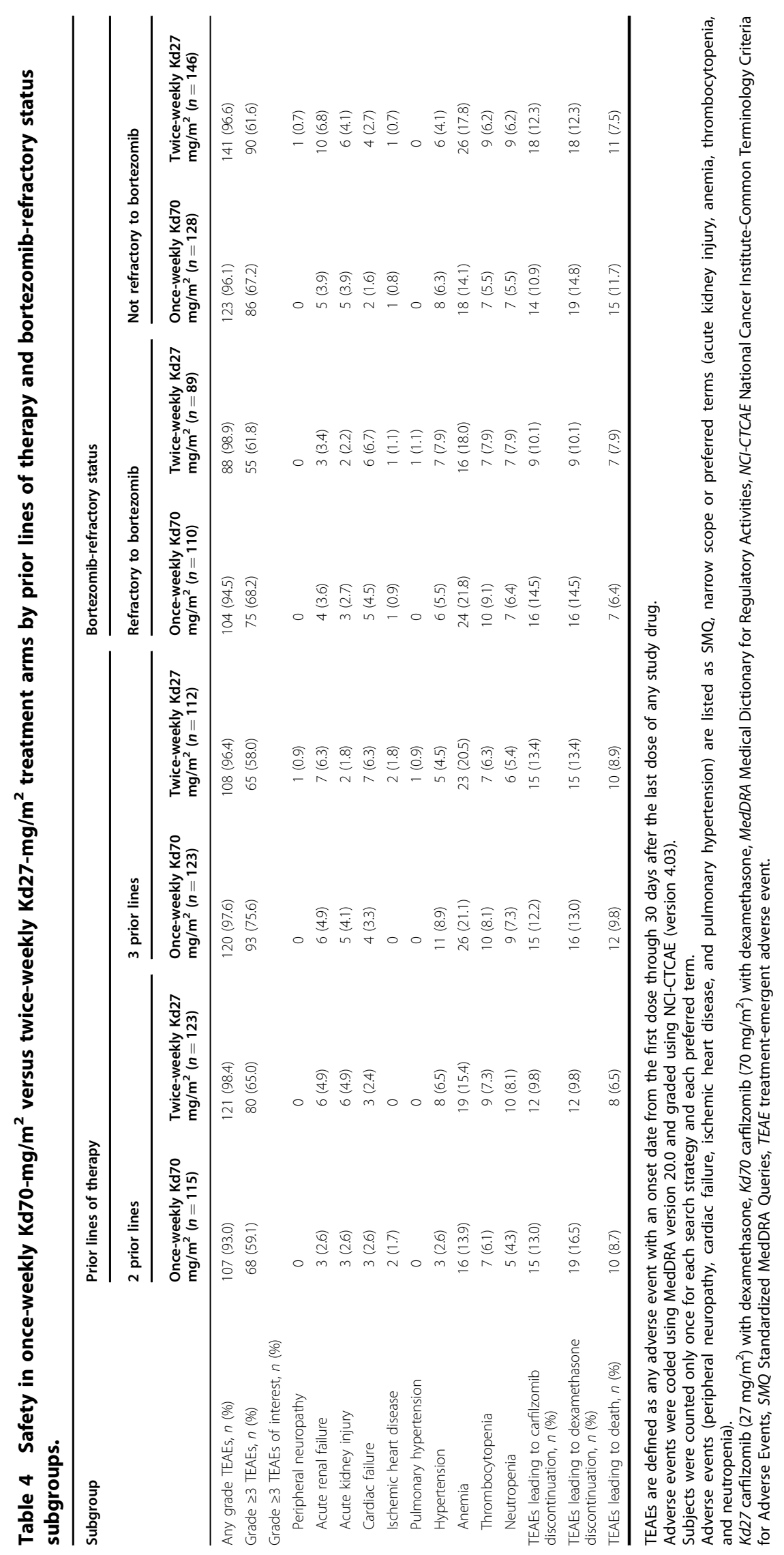


cardiac failure (once-weekly $\mathrm{Kd} 70 \mathrm{mg} / \mathrm{m}^{2}$ and twiceweekly $\mathrm{Kd} 27 \mathrm{mg} / \mathrm{m}^{2}$ ) by ISS stage were $2.3 \%$ and $4.0 \%$ (ISS stages 1 and 2 ) and $4.8 \%$ and $3.7 \%$ (ISS stage 3 ).

\section{Discussion}

In this pre-planned subgroup analysis of the A.R.R.O.W. study, patients were evaluated by age, renal function, prior lines of therapy, bortezomib-refractory status, ECOG PS, and ISS stage. These factors have demonstrated prognostic significance in $\mathrm{RRMM}^{6-10}$ and are important considerations when selecting therapy. Across nearly all examined subgroups in A.R.R.O.W., once-weekly administration of carfilzomib at the higher $70-\mathrm{mg} / \mathrm{m}^{2}$ dose in combination with dexamethasone was associated with longer median PFS and higher ORR compared with twiceweekly administration of carfilzomib at the $27-\mathrm{mg} / \mathrm{m}^{2}$ dose in combination with dexamethasone. These findings are consistent with those in the overall population ${ }^{27}$. Part of the observed benefit in patients receiving once-weekly $\mathrm{Kd} 70 \mathrm{mg} / \mathrm{m}^{2}$ in A.R.R.O.W. is likely due to the higher dose of carfilzomib administered in this treatment arm. Furthermore, patient-reported outcomes analysis reinforced that the higher $70-\mathrm{mg} / \mathrm{m}^{2}$ carfilzomib dose is convenient and provided more favorable health-related quality of life than the $27-\mathrm{mg} / \mathrm{m}^{2}$ carfilzomib dose ${ }^{13}$. Adherence to therapy might have improved for patients treated with once-weekly $\mathrm{Kd} 70 \mathrm{mg} / \mathrm{m}^{2}$ due to the more convenient weekly carfilzomib dosing schedule, which could have translated to improved clinical outcomes.

Elderly patients with MM are a challenging population to treat, in part due to higher chemotherapy toxicities ${ }^{30}$ and comorbidity burden ${ }^{31,32}$. In ENDEAVOR and ASPIRE, analyses of twice-weekly carfilzomib-based therapies by age demonstrated consistent improvements in PFS and OS compared with the control treatment arms across all subgroups ${ }^{20,21}$. In A.R.R.O.W., once-weekly $\mathrm{Kd} 70 \mathrm{mg} / \mathrm{m}^{2}$ improved PFS and ORR for all age subgroups versus twice-weekly $\mathrm{Kd} 27 \mathrm{mg} / \mathrm{m}^{2}$. Compared with the two older-age subgroups, patients in the younger subgroup (aged $<65$ years) received a greater median number of cycles of treatment in the once-weekly Kd70 $\mathrm{mg} / \mathrm{m}^{2}$ arm than in the twice-weekly $\mathrm{Kd} 27 \mathrm{mg} / \mathrm{m}^{2} \mathrm{arm}$. Since patients aged $<65$ years stayed on treatment longer with once-weekly $\mathrm{Kd} 70 \mathrm{mg} / \mathrm{m}^{2}$ compared with twiceweekly $\mathrm{Kd} 27 \mathrm{mg} / \mathrm{m}^{2}$ relative to the older-age subgroups, the younger-age patients receiving once-weekly $\mathrm{Kd} 70 \mathrm{mg} /$ $\mathrm{m}^{2}$ were able to derive a greater PFS benefit.

The safety profile for once-weekly $\mathrm{Kd} 70 \mathrm{mg} / \mathrm{m}^{2}$ was generally comparable to twice-weekly $\mathrm{Kd} 27 \mathrm{mg} / \mathrm{m}^{2}$ across all assessed age subgroups. In patients aged $<65$ years, the shorter median duration of carfilzomib administration in the twice-weekly $\mathrm{Kd} 27 \mathrm{mg} / \mathrm{m}^{2}$ arm (21.3 weeks) compared to once-weekly $\mathrm{Kd} 70 \mathrm{mg} / \mathrm{m}^{2}$ (41.1 weeks) may be partially explained by the higher incidence of disease progression or death in the twice-weekly $\mathrm{Kd} 27-\mathrm{mg} / \mathrm{m}^{2}$ arm (64.4\%) compared to the once-weekly Kd70-mg $/ \mathrm{m}^{2}$ arm $(51.0 \%)$ (Fig. 1a). In patients aged $\geq 75$ years, the higher incidence of grade $\geq 3$ TEAEs in the once-weekly $\mathrm{Kd} 70-\mathrm{mg} / \mathrm{m}^{2}$ group $(84.4 \%)$ compared to those in the twice-weekly $\mathrm{Kd} 27-\mathrm{mg} / \mathrm{m}^{2}$ group (74.2\%) may be due to the higher proportion of patients with baseline CrCL 30$<50 \mathrm{~mL} / \mathrm{min}$ (56.5\% versus $40.6 \%$ ). Overall, once-weekly $\mathrm{Kd} 70 \mathrm{mg} / \mathrm{m}^{2}$ was effective and well tolerated in patients with RRMM regardless of age. The improved convenience of the once-weekly dosing schedule could be important for elderly patients with restricted mobility or for those who are working.

Impaired renal function is a common clinicopathological feature of MM that has been associated with worse prognosis and survival in patients ${ }^{8}$. Furthermore, drug dosing can be complicated by renal impairment, which can increase or worsen $\mathrm{AEs}^{33}$. In a subgroup analysis of ENDEAVOR, twice-weekly Kd56 therapy demonstrated clinically meaningful improvements in PFS and OS across renal subgroups, including severe renal impairment, compared with bortezomib-based therapy ${ }^{26}$. Our results show that patients administered once-weekly $\mathrm{Kd} 70 \mathrm{mg} / \mathrm{m}^{2}$ had longer median PFS and higher response rates compared with twice-weekly $\mathrm{Kd} 27 \mathrm{mg} / \mathrm{m}^{2}$ across all renal function subgroups, including patients with baseline $\mathrm{CrCL}<50 \mathrm{~mL} / \mathrm{min}$.

In patients with baseline $\mathrm{CrCL}<80 \mathrm{~mL} / \mathrm{min}$, rates of grade $\geq 3$ TEAEs and TEAEs leading to treatment discontinuation were greater in the once-weekly Kd70-mg $/ \mathrm{m}^{2}$ group compared to the twice-weekly $\mathrm{Kd} 27-\mathrm{mg} / \mathrm{m}^{2}$ group. Specifically in patients with $\mathrm{CrCL}<50 \mathrm{~mL} / \mathrm{min}$, the incidence of TEAEs leading to carfilzomib treatment discontinuation was $28.6 \%$ for once-weekly $\mathrm{Kd} 70 \mathrm{mg} / \mathrm{m}^{2}$ compared with $14.7 \%$ for twice-weekly $\mathrm{Kd} 27 \mathrm{mg} / \mathrm{m}^{2}$. Similar rates of grade $\geq 3$ heart failure, hypertension, and acute kidney injury were reported for once-weekly Kd70 $\mathrm{mg} / \mathrm{m}^{2}$ and twice-weekly $\mathrm{Kd} 27 \mathrm{mg} / \mathrm{m}^{2}$ within each renal subgroup. Overall, once-weekly $\mathrm{Kd} 70 \mathrm{mg} / \mathrm{m}^{2}$ had a favorable benefit-risk profile relative to twice-weekly $\mathrm{Kd} 27 \mathrm{mg} / \mathrm{m}^{2}$ in patients with baseline $\mathrm{CrCL} \geq 50 \mathrm{~mL} / \mathrm{min}$. In patients with decreased renal function $(\mathrm{CrCL}<50 \mathrm{~mL} /$ $\mathrm{min}$ ), the once-weekly $\mathrm{Kd} 70-\mathrm{mg} / \mathrm{m}^{2}$ regimen improved PFS and response rates compared with the twice-weekly Kd27$\mathrm{mg} / \mathrm{m}^{2}$ regimen; however, a higher rate of AEs leading to carfilzomib treatment discontinuation was observed with once-weekly $\mathrm{Kd} 70 \mathrm{mg} / \mathrm{m}^{2}$. Taken together, once-weekly $\mathrm{Kd} 70 \mathrm{mg} / \mathrm{m}^{2}$ demonstrates benefit over twice-weekly Kd27 $\mathrm{mg} / \mathrm{m}^{2}$, although to a lesser extent in patients with $\mathrm{CrCL}$ $<50 \mathrm{~mL} / \mathrm{min}$.

Previously treated patients with RRMM are a challenging population to treat, as the disease has been reported to become less sensitive or refractory to certain therapies with each successive line of treatment ${ }^{6,34}$. Previous 
subgroup reports from ASPIRE $^{22}$ and ENDEAVOR ${ }^{23}$ demonstrated improved PFS and ORR of twice-weekly carfilzomib-based regimens compared to recent SOCs, regardless of the number of prior therapies patients had received before enrollment. Consistent with previous reports $^{22,23}$, a greater benefit was observed in patients with fewer previous therapies, suggesting that carfilzomib efficacy (administered once- or twice-weekly) can be optimized by earlier administration in the disease course for patients with RRMM.

The safety profiles for the prior lines subgroups were generally consistent with those reported for the overall population. In patients previously treated with three lines of therapy, the incidence of grade $\geq 3$ TEAEs was greater in the once-weekly $\mathrm{Kd} 70-\mathrm{mg} / \mathrm{m}^{2}$ treatment arm (75.6\%) compared with the twice-weekly $\mathrm{Kd} 27-\mathrm{mg} / \mathrm{m}^{2}$ arm (58.0\%). This may be partially due to the higher proportion of patients aged $75-84$ years $(22.6 \%$ versus $11.5 \%)$ in the once-weekly $\mathrm{Kd} 70-\mathrm{mg} / \mathrm{m}^{2}$ treatment arm. Importantly, the incidence of grade $\geq 3$ cardiac failure was $<7 \%$ across treatment arms and was lower for once-weekly $\mathrm{Kd} 70 \mathrm{mg} / \mathrm{m}^{2}(2.6 \%-3.3 \%)$, and no additional toxicities were found. This subgroup analysis confirmed that onceweekly treatment with carfilzomib $\left(70 \mathrm{mg} / \mathrm{m}^{2}\right)$ plus dexamethasone is safe, feasible, and superior to twice-weekly carfilzomib $\left(27 \mathrm{mg} / \mathrm{m}^{2}\right)$ plus dexamethasone, regardless of the number of prior therapies.

Bortezomib is a common component of frontline therapies, and there is a need for effective salvage options in patients whose disease becomes refractory to this agent. The ASPIRE trial previously reported improved PFS and OS in bortezomib-refractory patients treated with twiceweekly $\mathrm{KRd}$ versus $\mathrm{Rd}^{18,22}$. In A.R.R.O.W., patients treated with once-weekly $\mathrm{Kd} 70 \mathrm{mg} / \mathrm{m}^{2}$ demonstrated longer median PFS and higher ORRs versus those treated with twice-weekly $\mathrm{Kd} 27 \mathrm{mg} / \mathrm{m}^{2}$, regardless of disease sensitivity to bortezomib. In both treatment arms, absolute PFS durations and response rates were lower in patients with bortezomib-refractory disease compared with bortezomib-sensitive disease. This is consistent with the existence of some cross-resistance between the two $\mathrm{PIs}^{35,36}$. Taken together with ASPIRE, these results support the benefit of carfilzomib-based therapy for patients with disease refractory to bortezomib.

Safety profiles by bortezomib-refractory status were comparable to the overall population ${ }^{27}$. Once-weekly $\mathrm{Kd} 70 \mathrm{mg} / \mathrm{m}^{2}$ demonstrated improved efficacy with a similar safety profile compared to twice-weekly Kd27 mg/ $\mathrm{m}^{2}$, regardless of bortezomib-refractory status. As continuous treatment with lenalidomide has become a new SOC in frontline $\mathrm{MM}^{37,38}$, there is a need for active regimens to treat patients who have relapsed or become refractory to lenalidomide. In the A.R.R.O.W. trial, 401 (83.9\%) patients had prior lenalidomide exposure and 356
$(74.5 \%)$ were refractory to any prior lenalidomide ${ }^{27}$. Although lenalidomide-exposed and lenalidomiderefractory patient subgroups were not evaluated in this study, analyses from these subgroups are underway and will be presented in a separate paper.

ECOG PS (0-5) and ISS stages (1-3) are prognostic factors used to assess patients with $\mathrm{MM}^{39,40}$, with higher values associated with worse prognosis and greater susceptibility to AEs. In our study, grade $\geq 3$ TEAEs, including cardiac TEAEs, were comparable across treatment arms, regardless of ECOG PS (0 or 1) or ISS stage (stage 1 and 2 or stage 3). Once-weekly $\mathrm{Kd} 70 \mathrm{mg} / \mathrm{m}^{2}$, therefore, represents a tolerable therapeutic option in RRMM patients with advanced disease and functional impairment.

Limitations of this subgroup analysis of A.R.R.O.W. include the open-label trial design and the small numbers of patients in subgroups. In addition, the control group in our study was administered twice-weekly carfilzomib at a dose of $27 \mathrm{mg} / \mathrm{m}^{2}$ in combination with dexamethasone; the currently approved dose of carfilzomib in combination with dexamethasone is $56 \mathrm{mg} / \mathrm{m}^{2}$ (based on ENDEA$\left.\mathrm{VOR}^{15,16}\right)$, which was not yet approved during the enrollment period of the A.R.R.O.W. study. Nevertheless, findings from this study warrant further investigation.

Clinical practice guidelines from the National Comprehensive Cancer Network, American Society of Oncology, and Cancer Care Ontario recommend doublet and triplet regimens as treatment options for patients with previously treated $M^{41,42}$. In randomized trials, carfilzomib- and daratumumab-based triplets have improved PFS, ORR, and/or OS in relapsed and/or refractory MM patients relative to doublet therapies; however, triplet therapies were also associated with higher rates of toxicity in these studies ${ }^{17,18,43-46}$. Therefore, patients with lower tolerance for increased toxicity, higher comorbidity burden, and/or frail status may not be suited for triplet therapies ${ }^{42}$. Comparisons of once-weekly Kd70 $\mathrm{mg} / \mathrm{m}^{2}$ with currently available data from triplet combination studies are challenging, given differences in patient population (e.g., prior therapy, sensitivity to IMiDs and/or PIs, baseline creatinine clearance) and stratification of subgroups ${ }^{17,20,22,43-47}$. Future studies evaluating the efficacy and safety of once-weekly $\mathrm{Kd} 70 \mathrm{mg} / \mathrm{m}^{2}$ dosing relative to recommended triplet salvage regimens may further highlight the potential utility of once-weekly Kd70 $\mathrm{mg} / \mathrm{m}^{2}$ in the RRMM treatment armamentarium.

\section{Conclusions}

In this pre-planned subgroup analysis of the A.R.R.O.W. study, PFS and ORR were consistently improved in the once-weekly carfilzomib treatment arm at the higher 70$\mathrm{mg} / \mathrm{m}^{2}$ dose compared with the twice-weekly carfilzomib treatment arm at the $27-\mathrm{mg} / \mathrm{m}^{2}$ dose across several 
important baseline patient and disease characteristics. The safety profiles of once-weekly $\mathrm{Kd} 70 \mathrm{mg} / \mathrm{m}^{2}$ in each patient subgroup were generally consistent with that in the overall population ${ }^{27}$. Overall, this subgroup analysis of A.R.R.O.W. supports the favorable benefit-risk profile of once-weekly $\mathrm{Kd} 70 \mathrm{mg} / \mathrm{m}^{2}$ and the use of this regimen as a safe, effective, and convenient treatment option for patients with RRMM, regardless of age, prior lines of therapy, and bortezomib-refractory status.

\section{Acknowledgements}

Amgen, Inc. was the study sponsor and played a role in the design of the study, collection and analysis of the data, and in the decision to submit the paper for publication. Medical writing assistance was provided by Frances Xin, Sachi Yim, and Andrew Gomes of Ashfield Healthcare Communications, part of UDG Healthcare, plc, and funded by Amgen.

\section{Author details \\ ${ }^{1}$ National and Kapodistrian University of Athens, Athens, Greece. ${ }^{2}$ Center for Myeloma, New York Presbyterian Hospital-Weill Cornell Medical Center, New York, NY, USA. ${ }^{3}$ University Medical Center Hamburg-Eppendorf, Hamburg, Germany. ${ }^{4}$ University Hospital of Tuebingen, Tuebingen, Germany. ${ }^{5}$ John Theurer Cancer Center at Hackensack University Medical Center, Hackensack, NJ, USA. ${ }^{6}$ Department of Hematooncology, University Hospital Ostrava and Faculty of Medicine, University of Ostrava, Ostrava, Czech Republic. \\ ${ }^{7}$ Hematology Service, University Hospital, Salamanca, Spain. " Seràgnoli" Institute of Hematology and Medical Oncology, Bologna University School of Medicine, Bologna, Italy. ${ }^{9}$ Amgen, Inc., Thousand Oaks, CA, USA. ${ }^{10}$ Hematology Department, University Hospital Hotel-Dieu, Nantes, France}

\section{Author contributions}

All authors participated in manuscript writing and approved the final version of the manuscript. Conception and design of study: P.M. and M.-V.M. Acquisition of data: M.A.D., P.M., M.-V.M., and M.C. Statistical analysis: M.H. Analysis and interpretation of data: All authors.

\section{Conflict of interest}

M.A.D. has received consulting fees and honoraria from Amgen, Bristol-Myers Squibb (BMS), Takeda, Celgene, and Janssen. R.N. has received consulting fees and research funding from Takeda, Celgene, BMS, Amgen, and Janssen. K.W. has received honoraria from Amgen, BMS, Celgene, Janssen, Novartis, and Takeda; consulting fees from Amgen, Adaptive, BMS, Celgene, Janssen, Takeda, Sanofi, and Juno; and research funding from Amgen, Celgene, Sanofi, and Janssen. D.S.S. has received consulting fees from Takeda, Karyopharm, Merck, Celgene, Janssen, BMS, and Amgen; honoraria from Takeda, Karyopharm, Merck, Celgene, Janssen, BMS, Novartis, and Amgen; served on speakers' bureaus for Takeda, Merck, Celgene, Janssen, BMS, Novartis, and Amgen; and has received research funding from Celgene. R.H. has received consulting fees, honoraria, and research funding from Amgen, Takeda, Celgene, Janssen, AbbVie, Novartis, PharmaMar, and BMS. M.-V.M. has received consulting fees from and served on Board of Directors/advisory committees for AbbVie, Amgen, GlaxoSmithKline, Takeda, Janssen, and Celgene and honoraria from Amgen, Takeda, Janssen, and Celgene. M.C. has received honoraria from and served on Board of Directors/advisory committees for AbbVie, BMS, Takeda, GlaxoSmithKline, Adaptive Biotechnologies, Janssen, Celgene, and Amgen and served on speakers' bureaus for and received research funding from Janssen and Celgene. M.H. and A.Z.-K. are employees of, and own stock in, Amgen. P.M. has received honoraria from, and served on Board of Directors/advisory committees for, Amgen, Celgene, Janssen, Takeda, and AbbVie and served on speakers' bureaus for Amgen, Celgene, Janssen, and AbbVie.

\section{Publisher's note}

Springer Nature remains neutral with regard to jurisdictional claims in published maps and institutional affiliations.
Supplementary Information accompanies this paper at (https://doi.org/ 10.1038/s41408-020-0300-y).

Received: 29 June 2019 Revised: 11 December 2019 Accepted: 3 January 2020

Published online: 09 March 2020

\section{References}

1. Kumar, S. K. et al. Multiple myeloma. Nat. Rev. Dis. Primers 3, 17046 (2017).

2. Ferlay, J. et al. Cancer incidence and mortality worldwide: sources, methods and major patterns in GLOBOCAN 2012. Int. J. Cancer 136, E359-E386 (2015).

3. Cook, G., Zweegman, S., Mateos, M. V., Suzan, F. \& Moreau, P. A question of class: treatment options for patients with relapsed and/or refractory multiple myeloma. Crit. Rev. Oncol. Hematol. 121, 74-89 (2018).

4. Sonneveld, P. et al. Treatment of multiple myeloma with high-risk cytogenetics: a consensus of the International Myeloma Working Group. Blood 127, 2955-2962 (2016).

5. Dingli, D. et al. Therapy for relapsed multiple myeloma: guidelines from the Mayo stratification for myeloma and risk-adapted therapy. Mayo Clin. Proc. 92, 578-598 (2017).

6. Kumar, S. K. et al. Clinical course of patients with relapsed multiple myeloma. Mayo Clin. Proc. 79, 867-874 (2004).

7. Tandon, N. et al. Clinical utility of the Revised International Staging System in unselected patients with newly diagnosed and relapsed multiple myeloma. Blood Cancer J. 7, e528 (2017).

8. Eleutherakis-Papaiakovou, $\mathrm{V}$. et al. Renal failure in multiple myeloma: incidence, correlations, and prognostic significance. Leuk. Lymphoma 48, 337-341 (2007).

9. Willan, J. et al. Multiple myeloma in the very elderly patient: challenges and solutions. Clin. Inter. Aging 11, 423-435 (2016).

10. Laubach, J. et al. Management of relapsed multiple myeloma: recommendations of the International Myeloma Working Group. Leukemia 30, 1005-1017 (2016).

11. Kim, H. et al. Efficacy and safety of once-weekly bortezomib infusion in the treatment of relapsed/refractory multiple myeloma. Blood 118, 5141 (2011).

12. Hainsworth, J. D. et al. Weekly treatment with bortezomib for patients with recurrent or refractory multiple myeloma: a phase 2 trial of the Minnie Pearl Cancer Research Network. Cancer 113, 765-771 (2008).

13. Moreau, P. et al. Convenience, satisfaction, health-related quality of life of once-weekly $70 \mathrm{mg} / \mathrm{m}^{2}$ vs. twice-weekly $27 \mathrm{mg} / \mathrm{m}^{2}$ carfilzomib (randomized A.R.R.O.W. study). Leukemia https://doi.org/10.1038/s41375-019-0480-2 (2019).

14. Siegel, D. S. et al. A phase 2 study of single-agent carfilzomib (PX-171-003-A1) in patients with relapsed and refractory multiple myeloma. Blood 120, 2817-2825 (2012).

15. KYPROLIS ${ }^{\circledR}$. KYPROLIS ${ }^{\circledR}$ (carfilzomib) [prescribing information] (Onyx Pharmaceuticals, Inc, South San Francisco, CA, 2018).

16. Dimopoulos, M. A. et al. Carfilzomib and dexamethasone versus bortezomib and dexamethasone for patients with relapsed or refractory multiple myeloma (ENDEAVOR): a randomised, phase 3, open-label, multicentre study. Lancet Oncol. 17, 27-38 (2016).

17. Stewart, A. K. et al. Carfilzomib, lenalidomide, and dexamethasone for relapsed multiple myeloma. N. Engl. J. Med. 372, 142-152 (2015).

18. Siegel, D. S. et al. Improvement in overall survival with carfilzomib, lenalidomide, and dexamethasone in patients with relapsed or refractory multiple myeloma. J. Clin. Oncol. 36, 728-734 (2018).

19. Dimopoulos, M. A. et al. Carfilzomib or bortezomib in relapsed or refractory multiple myeloma (ENDEAVOR): an interim overall survival analysis of an openlabel, randomised, phase 3 trial. Lancet Oncol. 18, 1327-1337 (2017).

20. Dimopoulos, M. A. et al. Carfilzomib, lenalidomide, and dexamethasone in patients with relapsed multiple myeloma categorised by age: secondary analysis from the phase 3 ASPIRE study. Br. J. Haematol. 177, 404-413 (2017).

21. Ludwig, $H$. et al. Carfilzomib and dexamethasone vs bortezomib and dexamethasone in patients with relapsed multiple myeloma: results of the phase 3 study ENDEAVOR (NCT01568866) according to age subgroup. Leuk. Lymphoma 58, 2501-2504 (2017).

22. Dimopoulos, M. A. et al. Carfilzomib-lenalidomide-dexamethasone vs lenalidomide-dexamethasone in relapsed multiple myeloma by previous treatment. Blood Cancer J. 7, e554 (2017). 
23. Moreau, P. et al. Impact of prior treatment on patients with relapsed multiple myeloma treated with carfilzomib and dexamethasone vs bortezomib and dexamethasone in the phase 3 ENDEAVOR study. Leukemia 31, 115-122 (2017).

24. Avet-Loiseau, H. et al. Carfilzomib significantly improves the progression-free survival of high-risk patients in multiple myeloma. Blood 128, 1174-1180 (2016).

25. Chng, W. J. et al. Carfilzomib-dexamethasone vs bortezomib-dexamethasone in relapsed or refractory multiple myeloma by cytogenetic risk in the phase 3 study ENDEAVOR. Leukemia 31, 1368-1374 (2017).

26. Dimopoulos, M. A. et al. Superior efficacy of carfilzomib and dexamethasone (Kd56) vs bortezomib and dexamethasone (Vd) in multiple myeloma (MM) patients with moderate or serious renal failure: a subgroup analysis of the phase 3 ENDEAVOR study. Blood 130, 1845 (2017).

27. Moreau, P. et al. Once weekly versus twice weekly carfilzomib dosing in patients with relapsed and refractory multiple myeloma (A.R.R.O.W.): interim analysis results of a randomised, phase 3 study. Lancet Oncol. 19, 953-964 (2018).

28. Durie, B. G. et al. International uniform response criteria for multiple myeloma. Leukemia 20, 1467-1473 (2006)

29. Rajkumar, S. V. et al. Consensus recommendations for the uniform reporting of clinical trials: report of the International Myeloma Workshop Consensus Panel 1. Blood 117, 4691-4695 (2011).

30. Repetto, L. Greater risks of chemotherapy toxicity in elderly patients with cancer. J. Support. Oncol. 1(4 Suppl 2), 18-24 (2003).

31. Yancik, R., Ganz, P. A., Varricchio, C. G. \& Conley, B. Perspectives on comorbidity and cancer in older patients: approaches to expand the knowledge base. J. Clin. Oncol. 19, 1147-1151 (2001).

32. Qian, Y. et al. Renal impairment and use of nephrotoxic agents in patients with multiple myeloma in the clinical practice setting in the United States. Cancer Med. 6, 1523-1530 (2017).

33. Gabardi, S. \& Abramson, S. Drug dosing in chronic kidney disease. Med. Clin. North Am. 89, 649-687 (2005).

34. Kurtin, S. E. Relapsed or relapsed/refractory multiple myeloma. J. Adv. Pract. Oncol. 4(Suppl 1), 5-14 (2013).

35. Ziogas, D. C., Terpos, E., Kastritis, E. \& Dimopoulos, M. A. An overview of the role of carfilzomib in the treatment of multiple myeloma. Expert Opin. Pharmacother. 18, 1883-1897 (2017).
36. Muchtar, E. et al. Efficacy and safety of salvage therapy using Carfilzomib for relapsed or refractory multiple myeloma patients: a multicentre retrospective observational study. Br. J. Haematol. 172, 89-96 (2016).

37. Facon, T. et al. Final analysis of survival outcomes in the phase 3 FIRST trial of up-front treatment for multiple myeloma. Blood 131, 301-310 (2018).

38. Pulte, E. D. et al. FDA approval summary: lenalidomide as maintenance therapy after autologous stem cell transplant in newly diagnosed multiple myeloma. Oncologist 23, 734-739 (2018).

39. Dimopoulos, M. A., Terpos, E., Niesvizky, R. \& Palumbo, A. Clinical characteristics of patients with relapsed multiple myeloma. Cancer Treat. Rev. 41, 827-835 (2015).

40. Palumbo, A. et al. International Myeloma Working Group consensus statement for the management, treatment, and supportive care of patients with myeloma not eligible for standard autologous stem-cell transplantation. J. Clin. Oncol. 32, 587-600 (2014).

41. National Comprehensive Cancer Network (NCCN). NCCN Clinical practice guidelines in oncology: multiple myeloma version 2.2019. https://www.nccn. org/professionals/physician_gls/pdf/myeloma.pdf (2019). Accessed 15 October (2019).

42. Mikhael, J. et al. Treatment of multiple myeloma: ASCO and CCO Joint Clinical Practice Guideline. J. Clin. Oncol. 10, 1228-1263 (2019).

43. Dimopoulos, M. A. et al. Daratumumab, lenalidomide, and dexamethasone for multiple myeloma. N. Engl. J. Med. 375, 1319-1331 (2016).

44. Dimopoulos, M. A. et al. Daratumumab plus lenalidomide and dexamethasone versus lenalidomide and dexamethasone in relapsed or refractory multiple myeloma: updated analysis of POLLUX. Haematologica 103, 2088-2096 (2018).

45. Palumbo, A. et al. Daratumumab, bortezomib, and dexamethasone for multiple myeloma. N. Engl. J. Med. 375, 754-766 (2016).

46. Spencer, A. et al. Daratumumab plus bortezomib and dexamethasone versus bortezomib and dexamethasone in relapsed or refractory multiple myeloma: updated analysis of CASTOR. Haematologica 103, 2079-2087 (2018).

47. Mateos, M. V. et al. Daratumumab-based regimens are highly effective and well tolerated in relapsed or refractory multiple myeloma regardless of patient age: subgroup analysis of the phase 3 CASTOR and POLLUX studies. Haematologica https://doi.org/10.3324/haematol.2019.217448 (2019). 